\title{
Personal Income Tax Compliance in Nigeria: A Generalised Ordered Logistic Regression
}

\author{
Oluwafadekemi S. Areo ${ }^{1} \&$ Obindah Gershon ${ }^{1,2}$ \\ ${ }^{1}$ Department of Economics and Development Studies, Covenant University, Ota, Nigeria \\ 2 Co-Chair Center for Economic Policy and Development Research (CEPDeR), Covenant University, Ota, Nigeria \\ Correspondence: Oluwafadekemi S. Areo, Department of Economics and Development Studies, Covenant \\ University, Ota, Nigeria. E-mail: oluwafadekemiareo@yahoo.com
}

Received: March 19, 2020

doi:10.5430/rwe.v11n3p261
Accepted: May 11, 2020

Online Published: June 27, 2020

URL: https://doi.org/10.5430/rwe.v11n3p261

\begin{abstract}
This paper builds on already existing theoretical and empirical research on the economic and psychological factors used in explaining tax compliance. The likelihood that personal income taxpayers in Nigeria will be tax non-compliant, low tax compliant or tax compliant for either economic or psychological factors and a combination of both factors are evaluated using the Generalised ordered logistic regression. The findings in this paper provide extra information on the mixed results that have been obtained by empirical research on the subject matter of tax compliance by revealing how economic and psychological factors have different likelihood values for individuals to fall into the tax compliant category. This paper recommends that a proper analysis of the peculiar traits of the Nigerian tax system be conducted before decisions are made on either of the economic or psychological factors to be employed, to move personal income taxpayers to the tax compliant category.
\end{abstract}

Keywords: tax compliance, personal income tax, generalised ordered logistic regression, economic factors, psychological factors

\section{Introduction}

Since the global financial and economic crises of 2007/2008, strengthening tax compliance has over time become a core development objective in improving tax revenue generation and in aiding a better Domestic Revenue Mobilisation (DRM), in both advanced and developing countries (International Monetary Fund-IMF, 2015; Keen, Toro, Baer, Perry, Norregaard, Ueda, Rojas, Brondolo, Cleary, Hutton, Luca, Thackray, Wingender, Kapoor, Narasimhan, Ruzvidzo, Venon \& Prado, 2015). In developing countries, Nigeria inclusive, the achievement of the Sustainable Development Goals (SDGs) in 2030 requires tax revenue to Gross Domestic Products (GDP) ratio to grow by at least 5 percent annually and be at least 15-20 percent to effectively finance health, education, power, transportation, and sanitation; which are key targets of the SDGs (Gasper, Amaglobeli, Escribaro, Prady \& Soto, 2019; Gupta \& Plant, 2019; Prichard, Lustig, Gupta, Krafchik, Gary \& Coulibaly, 2019; World Bank, 2018; United Nations, 2017). However, among Sub- Saharan African (SSA) countries, Nigeria has one of the lowest tax revenue to GDP ratio of about 6.5 percent (Umar, Derashid, Ibrahim \& Bidin, 2019; IMF fiscal monitor, 2018).

In Nigeria, the issue of tax non-compliance is present in both the formal and informal sectors, among the wealthy and the poor, among corporate bodies as well as Entrepreneurs. Income taxes are paid mainly by persons who are formally employed, and large corporations (Kangave, Nakato, Waiswa, Nalukwago \& Zzimbe, 2018). Out of the 200 million Nigerians and the 65 million economically active persons; all the states and the Federal Capital Territory inclusive, only about 10 percent pay taxes (Oyedele \& Erikume, 2019). There are also about 130,000 high net worth individuals and companies in Nigeria; however, taxing these individuals has been very challenging (PWC, 2017). In a survey carried out by the Nigerian Economic Summit Group (NESG) in 2018, out of the 16,228 households that were interviewed, 13,066, that is about 81 percent of the respondents did not pay income taxes in the previous year. While for the few that paid, more than 70 percent paid for one month, out of 12 months (International Centre for Tax and Development-ICTD, 2019).

Empirical and theoretical efforts have identified the determinants of tax compliance as either belonging to the economic school of thought or the psychological school of thought. The economic factors are tax rates, tax penalties, 
and the probability of being detected for tax non-compliance (Oladele, Aribaba, Ahmodu \& Yusuff, 2019; Alkahtib, Abdul-jabbar \& Marimutu, 2018; Alm, Jackson \& Mckee, 1992; Allingham \& Sandmo, 1972). While the psychological factors include taxpayers' perception of the government, tax morale, age, sex, tax education and knowledge, personal values and beliefs, social norms, peer effects, trust in the government, provision of public goods as well as eliciting taxpayers' preferences (Umar et al., 2019; Da silva, Gurrereio \& Flores, 2019; Alasfour, 2019; Bird \& Nozemack 2018; Gobena \& Dijke, 2017).

The psychological tax contract proposes a combination of both economic and psychological factors to bring about tax compliance, with loyalty, trust, fairness, and rewards acting as binding elements of these two factors (Jayawardane, 2015; Feld \& Frey, 2006). In this contract, punishments play a role to provide a form of deterrence, but taxpayers' satisfaction with procedural justice, interaction justice, and distributive justice is what boosts their motivation to pay (Krishnan, Marinich \& Shields, 2012; Feld \& Frey, 2006). According to the study on tax compliance carried out by Feld \& Frey (2006), these factors need to be properly combined and utilised on a country-specific basis to bring about an improved tax compliance rate.

The search for a sustainable solution to tax non-compliance has remained a paramount agenda for the Nigerian government and the tax authorities. To improve personal income tax compliance rate in Nigeria, the Nigerian government, as well as the tax authorities, have employed some economic factors like reduction or increase in tax rates, carrying out tax audits to detect non-compliant persons, as well as meting out penalties to tax offenders (Oladele et al., 2019). Also, Psychological factors like a reduction of tax burdens, provision of tax incentives, tax amnesties, as well as rewards for compliant citizens have been implemented (Oladele et al., 2019). Although the number of taxable adults in Nigeria increased from about 10 million to about 20 million people in 2018, tax compliance rate is still less than 20 percent, and comprises 4 percent of people whose taxes are not deducted at source and 96 percent of persons whose taxes are deducted at source (Osibanjo, 2018; Pricewaterhousecoopers-PWC, 2017).

Some of the recent empirical research on economic factors for tax compliance in developing countries and Nigeria have found significant positive relationships (Oladele, Aribaba, Ahmodu \& Yusuff, 2019; Olaoye \& Ekundayo, 2019; Umar, Derashid, \& Popoola, 2018; Alkahtib, Abdul-Jabbar \& Marimutu, 2018). The other studies explained that psychological factors and a combination of economic and psychological factors drive tax compliance in developing countries, Nigeria inclusive (Koessler, Torgler, Feld, \& Frey, 2019;; Umar, Ibrahim, Derashid \& Bidin, 2019;; Ayuba, Saad, \& Ariffin, 2018; Nikiema \& Zahonogo, 2017; Mas'ud, Manaf, \& Saad, 2014). However, these studies just made conclusions about the extent to which these factors explain tax compliance, with no breakdown of the extent to which these factors move tax non-compliant citizens to become tax compliant. Perhaps, the findings from these empirical researches on tax compliance have not provided full details on how economic and psychological factors explain tax compliance in Nigeria and as such, the focus has been on less likely factors or less likely combination of factors.

In trying to understand why personal income tax compliance has been low in Nigeria, this paper employs the Generalised ordered logistic regression to evaluate the likelihood of Nigerians to be either tax non-compliant, low tax compliant or tax compliant when economic factors, psychological factors and a combination of both factors are put in place. In evaluating tax compliance, this methodology allows for the relaxation of the assumption of equal odds for falling into either tax non-compliant, low tax compliant or tax compliant categories as the explanatory variables increases. Best to the knowledge and review of literature by the researchers, only a few studies have used this methodology in explaining tax compliance in developing countries, with no study conducted for Nigeria (Radulovic, 2019; Ozdemir, Celik \& Kara, 2019). This paper also contributes to the existing literature by ascertaining the economic and psychological factors with the most impact on personal income tax compliance in Nigeria based on the findings from the Generalised ordered logistic regression analysis.

\section{Insights From Extant Studies}

Tax compliance is deciding to pay taxes for the benefit of society and at the expense of personal benefits (Djike, Gobena \& Verboon, 2019). It is the will of the taxpayer to act according to the spirit and letter of tax rules and regulations and tax administration without the use of coercion (Newman, Mwandambira, Charity \& Ongayi, 2018).

\subsection{Theoretical Review}

\subsubsection{Economic Deterrence Theory}

As described by Allingham \& Sandmo (1972), economic deterrence explains tax compliance with respect to tax rates, probability of being detected for evasion, and the penalties and threats of punishments (Ali, Fjelstad \& Sjursen, 
2013). The three principles of this theory are certainty; which represents a surety, severity; which represents the weight of punishment, and celerity; which means how fast these punishments would be given to defaulters. It should also be noted however that in the course of achieving this seamless tax collection process using deterrence, the taxpayers' would try to test their chances of being caught and where they find higher chances, they would then decide to go on ahead to comply. Where they find lower chances, they would look for loopholes to evade taxes (Frey and Feld, 2006; Sandmo, 2004). This is because the theory assumes that taxpayers' calculate the costs and opportunities of their actions before taking any actual decision. As such, the taxpayer is applying the economic rationale that makes them evade taxes as much as the payoff from evasion exceeds the supposed cost of being found non-compliant (Pfister, 2009).

\subsubsection{Theory of Planned Behavior}

In the field of psychology, the theory that explains the relationship between beliefs and behaviours is known as the Theory of Planned Behaviour (TPB). It explains the depth of human behaviour and asserts that attitudes, subjective norms, and perceived behavioural controls are the factors that shape human behaviour (Ameyaw, Abruquah \& Ashalley, 2016). This theory is an extension of the Theory of Reasoned Action (TRA) which was specifically based on human voluntary behaviour and behavioural control. TPB explains human behaviour as being deliberate and calculated and that whether or not a behaviour will be performed is best predicted by the intention of coming out with a planned behaviour (Ajzen, 1991).

\subsubsection{Psychological Tax Contract}

The recommendations of the slippery slope framework were regarded as constituting a shaky ground according to Feld and Frey (2006). The psychological tax contract by Feld \& Frey (2006) first examined the voluntary exchange between citizens and the government, which emphasizes a contractual relationship; as proposed by Wicksellian (1986). The psychological tax contract is a step further from just focusing on the fiscal exchange, deterrence, monetary benefits, and the provision of public goods and services. This contract emphasises loyalties and emotional ties in upholding the social contract that exists between the citizens and the government. It is from these close ties that tax morale is built and positively affects tax compliance (Jayawardane, 2015).

Brooks (2001) explains that the possibility that a taxpayer will be compliant is based on some psychological factors that range from the morals and behavioural attitude of the taxpayer. Willingness to comply to tax laws as well as how taxpayers understand these laws, their social and personal norms all come together to influence the level of compliance that they have to taxation (Kirchler, 2007; Braithwaite, 2003).

Apart from loyalties and bonds, rewards are also of high importance as well as the policies of the government, the tax authorities, and the institutions. The contractual relationship of taxation specifies the rights and duties of each side of the contract and each side is meant to uphold their commitments (Haning \& Haniasti, 2019; Feld \& Frey, 2006). The government provides goods and services while the citizens pay their taxes. The psychological tax contract also entails distributive, interactional, and procedural justice; where procedural justice is concerned with fairness, interactional justice is concerned with respect, and distributive justice is concerned with the gains. The taxpayers and tax authorities are assumed to act like partners who trust each other and have respect for one another. When the reverse of this occurs, the psychological tax contract will be violated and there would be possibilities of tax non-compliance. The clause, however, is that tax authorities will only respect taxpayers when they are sure that tax morale is high (Krishnan, Marinich \& Shields, 2012).

In this contract, punishments play a role to provide a form of deterrence, but taxpayers' satisfaction with procedural, interaction and distributive justice is what boosts their tax morale. Therefore, in the psychological tax contract, the focus is not just one factor of tax compliance; but on a dynamic relationship between deterrence, monetary rewards, fiscal exchange, procedural, and distributive justice (Feld \& Frey, 2006). The merits of this contract are as follows:

i. Quasi-voluntary tax compliance: A steady reduction in taxpayers' compliance is examined not just from tax evasion or tax avoidance, but also taxpayers' discontentment with the tax system as a whole.

ii. Fair procedures are important: This contract works in a democratic system and requires citizens' involvement in political decision making.

iii. Proper treatment of the people by the tax authorities: It emphasizes that treating people with utmost respect goes a long way in changing their negative attitudes towards taxation. Procedures for audits are to be fair and transparent. 


\subsection{Empirical and Methodological Review}

\subsubsection{Studies on Economic Factors and Tax Compliance}

Akhatib, Abdul-Jabbar and Marimutu (2018) focused on the influence of deterrence factors on income tax evasion among the small business owners in Palestine. Using partial least square regression analysis, the factors tax penalty and the probability of being detected for tax evasion were statistically significant in explaining tax compliance but were negatively related to tax compliance. On the other hand, Olaoye and Ekundayo (2019) studied the effects of tax audit on tax compliance in Nigeria, using Ekiti as a case study. The result of the Multinomial logistic regression analysis revealed that tax audit was not statistically significant in explaining tax compliance in Nigeria. It was therefore concluded that the effect of tax audit on tax compliance in Nigeria is not concrete.

Using the Taro Yamane formula and judgment sampling technique Oladele, Aribaba, Olamide Ahmodu, Yusuff, and Alade, (2019) assessed the effectiveness of tax enforcement tools for improving tax compliance and overall tax income in the Ondo State, Nigeria. From the Ordinary Least Square regression analysis, tax audit and tax penalty indicated a positive and significant relationship with tax compliance in Ondo State, however, no meaningful association exists between tax amnesty and tax compliance based on the finding of this study. While, Umar, Derashid and Popoola (2019) asserted that tax audits in developing countries must be done as a three-dimensional process consisting of audit probability, detection and sanction rather than a holistic audit probability. The study argued that these three aspects are distinct and must all work together to ensure an effective audit before the audit process can serve as a deterrent. They also proposed that practitioners should measure tax audit effectiveness based on the three dimensions as put forward in the study.

\subsubsection{Studies on Psychological Factors and Tax Compliance}

In understanding how culture and trust in government reduce personal income tax non-compliance, Uadiale, Fagbemiand Ogunleye (2010) utilised the chi-square statistics and the Ordinary Least Square (OLS) regression. Trust in government and culture was postulated as having a significant positive relationship with reducing tax non-compliance in Nigeria. Data for this analysis was only from one state in Nigeria. Likewise, in explaining the concept of tax morale in Turkey, Ozdemir, Celik and Kara (2019) made use of the standard probit model, the generalised ordered logistic regression, the partial proportional odds model and the heteroscedastic ordered logit model. Their findings revealed marital status, income, and education as positively related to higher levels of tax compliance. Tax amnesty, past experiences, and tax burden were said to also significantly affect tax morale in Turkey.

Using a binary logistic regression, Ali, Fjelstad and Sjursen (2013) examined the determinants of tax compliance attitudes in four African countries including Kenya, Tanzania, Uganda, and South Africa. It was concluded that the difficulty of citizens to evade taxes improves the likelihood of tax compliance in Kenya and Tanzania and satisfaction with public goods and services is more likely to improve tax compliance in all the four countries studied. In Tanzania and South Africa, ethnic group bias reduces tax compliance behaviour, while improved tax knowledge improves tax compliance in these two countries. There was, however, no examination of the effects that deterrence factors will have on the findings. Umar, Ibrahim, Derashid and Bidin (2019) examined the relationship between public governance quality and tax compliance behaviour in developing countries. Their conceptual paper was focused on socioeconomic conditions serving as a mediator between the government and the citizens. They concluded that dissatisfaction with the system leads to the boycott of the tax system and in turn affects economic development. However, being a conceptual effort, they could not properly explain socio-economic conditions in all developing countries as these are country-specific characteristics.

\subsubsection{Studies That Combined Economic and Psychological Factors in the Explanation of Tax Compliance}

Using an ordered probit regression analysis, Yesegat and Fjelstad (2016) examined the determinants of tax compliance behaviour among business people in Ethiopia. It was concluded that the perception of audit, peer influence, political legitimacy, and demographic factors had a significant association with tax compliance. However, higher education attainments had a negative relationship with tax compliance. This study only reported that education and tax compliance had a significant negative relationship but did not specify if the relationship between tax compliance and the other variables were positive or negative; however significant. Also, De Neve, Imbert, Spinnewijn, Tsankova and Lots (2019) conducted experiments using deterrence, tax morale, and simplification of information to explain tax compliance among income taxpayers in Belgium. From their experiments, it was concluded that quality and simplified communication of tax issues improves tax compliance; deterrence factors have positive effects on tax compliance; tax morale through improved knowledge and satisfaction with public services 
does not bring about tax compliance. Quality and simplified communications were therefore postulated as the most cost-effective and most significant determinant of tax compliance.

Supriyadi (2017), aimed to study tax compliance behaviour in Indonesia using three techniques (quasi-experiment issues, survey analysis, and field experiment). Using the OLS regression and probit model estimation, the study sought to examine the relationship between trust and tax morale. It found that a negative correlation exists between vertical trust and tax morale in Indonesia; which indicates low institutional trust. The study investigated the effect of increased tax compliance monitoring using quasi-experiment and found that increased monitoring has a positive effect on reported income by the high wealth individual taxpayer. Finally, using the field experiment method, the study examined the effects of three behavioural interventions on tax compliance of individual and companies in Indonesia by inducing the perceived probability of audit, perceived fairness and moral persuasion. Using a difference-in-differences approach, the study found that perceived probability of audit intervention has a positive effect on reported other income of individual taxpayers, while the effects of perceived fairness and moral persuasion interventions varied among outcome variables and types of taxpayers. The study also does not find significant effects of interventions on the compliance behaviour of firm taxpayers. Finally, the study does not find that repeated interventions have an overall significant effect.

\section{Methodology}

\subsection{Theoretical Framework}

This study adapts the idea of the psychological tax contract proposed by Feld and Frey (2006). In this contract, tax compliance is the result of a complex interaction between economic deterrence measures and psychological factors. It explains that these psychological factors can be used to improve tax compliance while resorting to deterrence factors where necessary. The psychological tax contract builds a fiscal relationship between citizens and government, which in turn, creates the fiscal exchange between the two parties. This contract goes beyond deterrence and psychological factors as it explains the roles of loyalty and trust as the binding factors that allow the benefits of the economic and psychological factors to be harnessed. It, therefore, views tax compliance, which of course reflects taxpayers' intrinsic motivation to pay, as a function of the fiscal exchange between the citizens and the government; the political activities involved in getting to the fiscal exchange point; the close ties and trust between the taxpayers and the government.

The conceptual framework for this study is obtained through the modification of the recommended framework in the tax compliance studies carried out by Youde and Lim (2019), Kirchler (2019). Youde and Lim (2019), explained tax compliance as being determined by the interactions between economic and institutional variables such as tax laws, tax awareness, tax audits, tax morale, and trust in the government. Kirchler (2019) also provided a path through which tax compliance is obtained in his research work by postulating a balance between economic factors and psychological factors. The conceptual framework of this study is such that personal income tax compliance in Nigeria would be explained by:

i. The fiscal exchange between the government and Nigerians which entails the provision of public goods and services for taxes paid;

ii. The political activities that are set in motion to bring about a successful fiscal exchange and includes both economic and psychological factors such as the probability of mot being detected for tax non-compliance, tax rates, tax penalties, tax education, tax awareness, the strength of institutions, citizens' voice on tax issues, quality communication of tax-related issues, and tax fairness;

iii. The binding variable 'trust' ensures that the use of all factors brings about tax compliance. 


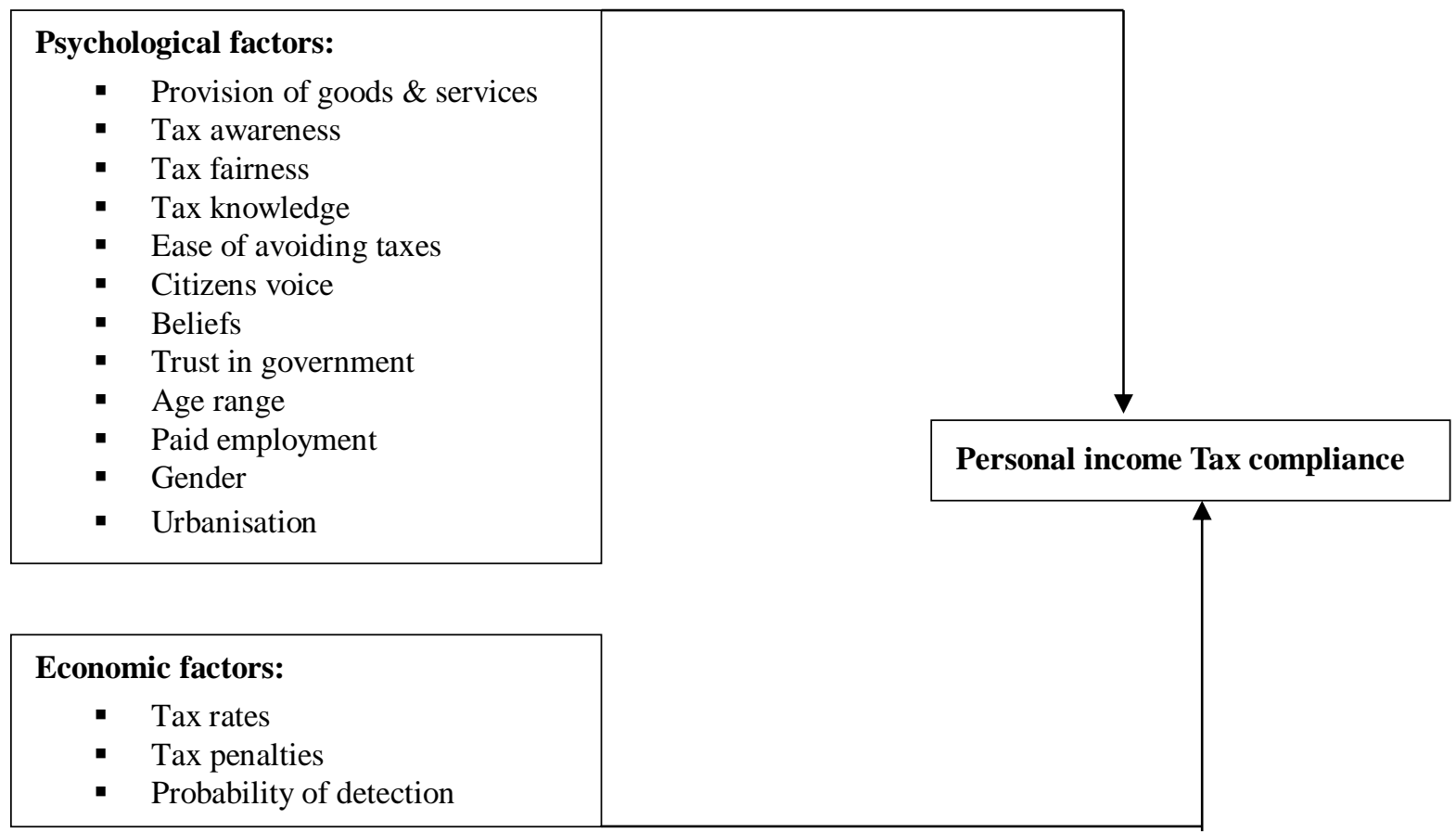

Figure 1. Schematic framework for personal income tax compliance in Nigeria

Source: Authors' computation

The schematic framework in Figure 1 depicts the path flow from psychological factors to personal income tax compliance and from economic factors to personal income tax compliance in Nigeria.

\subsection{Method of Analysis}

\subsubsection{Model Specification}

To achieve the research objectives of this study, the model for this research is specified in line with the adapted conceptual framework presented in Section 3.2. The model is first written in its implicit form.

For research objective one which is to assess the likelihood of being either tax non-compliant, low tax compliant or tax compliant in Nigeria when economic factors are utilised, the implicit form of the model is thus:

$$
T C=f\left(T P_{i}, P D_{i}, T R_{i}\right)
$$

Where:

TC: Tax compliance

$T P_{i}$ : Tax penalty

$P D_{i}$ : Probability of detection

$T R_{i}$ : Tax penalty

For the second research objective which is to examine the likelihood of being either tax non-compliant, low tax compliant or tax compliant in Nigeria when psychological factors are utilised, the implicit form of the model is thus:

$$
T C=f\left(S G_{i}, T F_{i}, T K_{i}, T A_{i}, Q I_{i}, C V_{i}, T_{i}, B L_{i}, A R_{i}, P E_{i}, G E_{i}, U R_{i}\right)
$$

Where:

$S$ : Provision of socioeconomic goods

$T F_{i}$ : Tax fairness

$T K_{i}$ : Tax knowledge

$T A_{i}$ : Tax awareness

$Q I_{i}$ : Quality institutions 
$C V_{i}$ : Citizens' voice

$T_{i}$ : Trust in government

$B L_{i}$ : Beliefs

$A R_{i}$ Age range

$P E_{i}$ : Paid employment

$G E_{i}:$ Gender

$U R_{i}$ : Urbanisation

For the third research objective which is to investigate the extent to which a combination of economic and psychological factors make Nigerians either tax non-compliant, low tax compliant or tax compliant, the implicit form of the model is thus written as:

Where:

$$
T C=f\left(T P_{i}, P D_{i}, T R_{i}, S G_{i}, T F_{i}, T K_{i}, T A_{i}, Q I_{i}, C V_{i}, T_{i}, B L_{i}, A R_{i}, P E_{i}, G E_{i}, U R_{i}\right)
$$

All the variables are as defined in equation (1) and (2)

All the implicit models above can be rewritten in their linear form. The general form of a linear model is such that:

Where:

$$
Y_{i}=\alpha_{0}+\alpha_{1} X_{i}+\varepsilon_{i}
$$

$Y_{i}$ : Dependent variable

$\alpha_{0}$ : Intercept term

$\alpha_{1}$ : Vector of parameters to be estimated

$X_{i}$ : Explanatory variables

$\varepsilon_{i}$ : Error term distributed normally

Therefore, equation (1), (2), and (3) can be rewritten respectively as follows:

$$
\begin{gathered}
Y_{i}=\alpha_{0}+\alpha_{1} T P_{i}+\alpha_{2} P D_{i}+\alpha_{3} T R_{i}+\varepsilon_{i} \\
Y_{i}=\alpha_{0}+\alpha_{1} S G_{i}+\alpha_{2} T F_{i}+\alpha_{3} T K_{i}+\alpha_{4} T A_{i}+\alpha_{5} Q U_{i}+\alpha_{6} C V_{i}+\alpha_{7} T_{i}+\alpha_{8} B L_{i}+\alpha_{9} A R+\alpha_{10} P E_{i}+\alpha_{11} G E_{i}+ \\
\alpha_{12} U R_{i}+\varepsilon_{i} \\
Y_{i}=\alpha_{0}+\alpha_{1} T P_{i}+\alpha_{2} P D_{i}+\alpha_{3} T R_{i}+\alpha_{4} S G_{i}+\alpha_{5} T F_{i}+\alpha_{6} T K_{i}+\alpha_{7} T A_{i}+\alpha_{8} Q U_{i}+\alpha_{9} C V_{i}+\alpha_{10} T_{i}+\alpha_{11} B L_{i}+ \\
\alpha_{12} A R_{i}+\alpha_{13} P E_{i}+\alpha_{14} G E_{i}+\alpha_{15} U R_{i}+\varepsilon_{i}
\end{gathered}
$$

Where:

$Y_{i}:$ Tax compliance

$\alpha_{1}, \alpha_{2}$ and $\alpha_{3}$ are slope coefficients

All explanatory variables are as previously defined

\subsubsection{Data Description}

This research utilised the 2018 Nigerian Economic Summit Group (NESG) quantitative survey dataset on households' attitudes and perceptions towards tax compliance in Nigeria. The survey was created to be very representative at the national level, geopolitical zones, urban/rural areas, and gender. It included a sample total of 16228 respondents. The basic methodology for data collection was in-home and face to face personal interviews using clustered, stratified, and multistage random selection method to achieve a representative sample. The respondents' selection process was based on a random selection of sampling start points, a random selection of households, and stratified random selection of eligible respondents. Households were sampled from all states (proportionate to their populations), there was a 50:50 gender balance, and respondents from urban areas made up 70 percent while those from rural areas made up 30 percent. To further make the dataset robust, extensive qualitative research was also conducted including FGDs and In-Depth Interviews (IDIs) with tax officials in selected states. The survey excluded non-Nigerian citizens, people aged less than 18 years, and people living in institutionalised settings. This study therefore selected indicators from this household survey data, relating to each research objective. For this study however, all the 16228 respondents in the NESG household survey data were utilised to ensure that this study remains representative of the 
perception of directly assessed personal income taxpayers in Nigeria.

\subsubsection{Data Availability Statement}

The data that support the findings of this study are openly available in [International Center for Tax and Development] at [https://www.ictd.ac/dataset/nesg-nigeria-tax-subsidy-perception-dataset/].

\subsubsection{Estimation Technique}

The review of the literature revealed different methodologies used in explaining the determinants of tax compliance. These techniques include descriptive and logistic regression analysis, ordered logistic regression, probit regression, fixed-effect analysis, as well as weighted least squares. In this study, however, the evaluation of the likelihood of Nigerians to be either tax non-compliant, low tax compliant or tax compliant when economic factors, psychological factors and a combination of both factors are employed is conducted using the Generalised ordered logistic regression. This technique is appropriate for this study because of the ranked ordinal nature of the dependent variable employed as well as the relaxation of the assumption of proportional odds between the different tax compliance categories.

This technique has greater advantages over the other types because most times, in reality, the proportional odds assumption is violated as one or more of the regression coefficients may differ across the categories of the dependent variable (Williams, 2006). It is a simpler method and does not need to estimate several parameters like other non-ordinal estimation techniques that relax the proportional odds assumption. The generalised ordered logistic regression model for this study was estimated using the gologit2 command, which is a Stata user-written command. It was created in line with the gologit command created by Vincent Fu in 1998. However, gologit2 has more strength as it can also be used to estimate logistic regression, partial proportional odds models as well as proportional odds models.

The Generalised Ordered Logistic regression model for this study is specified according to Fullerton and Xu (2016). It can thus be written as:

$$
P_{r}(y=z \mid X)=\left\{\begin{array}{c}
F\left(\omega_{1}-X \alpha_{1}\right) \\
F\left(\omega_{z}-X \alpha_{z}\right)-F\left(\omega_{z-1}-X \alpha_{z-1}\right) \\
1-F\left(\omega_{z-1}-X \alpha_{z-1}\right)
\end{array}\right\}
$$

Given that $z=1$,

$1<z \leq Z-1$,

$z=Z$

Where $\mathrm{F}$ is the logistic Cumulative Density Function (CDF);

$\alpha$ is a vector of logit coefficients that varies freely across logit equation;

$X$ is a vector of independent variables;

$\omega$ is a cut-off point;

$z$ is the logit

\section{Results and Discussions}

\subsection{Results}

Table 1. Tax compliance and economic factors

\begin{tabular}{|c|c|c|c|c|c|}
\hline Variables & $1^{\text {st }}$ panel & $2^{\text {nd }}$ panel & $\begin{array}{l}\text { Tax } \\
\text { non-compliance }\end{array}$ & $\begin{array}{l}\text { Low tax } \\
\text { compliance }\end{array}$ & Tax compliance \\
\hline Tax rate & $\begin{array}{l}1.071 \\
(0.065)\end{array}$ & $\begin{array}{l}1.191 \\
(0.000)\end{array}$ & $\begin{array}{l}\text { High: } 45 \% \\
\text { Low: } 9 \%\end{array}$ & $\begin{array}{l}\text { High: } 50 \% \\
\text { Low: 62\% }\end{array}$ & $\begin{array}{l}\text { High: } 5 \% \\
\text { Low:28\% }\end{array}$ \\
\hline Tax penalty & $\begin{array}{l}2.580 \\
(0.000)\end{array}$ & $\begin{array}{l}2.839 \\
(0.000)\end{array}$ & $\begin{array}{l}\text { Big: } 4 \% \\
\text { Small: } \mathbf{2 2 \%}\end{array}$ & $\begin{array}{l}\text { Big: } 45 \% \\
\text { Small: } \mathbf{6 5 \%}\end{array}$ & $\begin{array}{l}\text { Big: } 50 \% \\
\text { Small: } \mathbf{1 3 \%}\end{array}$ \\
\hline $\begin{array}{l}\text { Probability of no } \\
\text { detection }\end{array}$ & $\begin{array}{l}0.849 \\
(0.000)\end{array}$ & $\begin{array}{l}0.826 \\
(0.000)\end{array}$ & $\begin{array}{l}\text { High: } 18 \% \\
\text { Low: } \mathbf{2 4 \%}\end{array}$ & $\begin{array}{l}\text { High: } 66 \% \\
\text { Low:64\% }\end{array}$ & $\begin{array}{l}\text { High: } 12 \% \\
\text { Low: } \mathbf{1 6 \%}\end{array}$ \\
\hline
\end{tabular}

Source: Authors' computation 
The first null hypothesis states that there is no significant relationship between being either tax non-compliant, low tax compliant or tax compliant and economic factors in Nigeria. In Table 1, the first panel represents tax non-compliance as against low tax compliance and tax compliance. While the second panel represents tax non-compliance and low tax compliance as against tax compliance. The results for each panel are the odds ratio and the probability of the Z-statistics ratio in parenthesis. The other columns to the right are the predicted probabilities at different tax compliance categories or different levels of the explanatory variables. A more detailed display of the results is presented in the Appendices.

The first panel of Table 1 reveals a non-statistically significant and positive relationship between tax rates and moving an individual from being tax non-compliant to becoming low tax compliant or tax compliant. In the second panel, tax rate is statistically significant and positive when explaining the shift in an individual from being tax non-compliant or low tax compliant to becoming tax compliant. The odds ratio when tax rate is employed as a tax compliance determinant shows that the odds of a person becoming tax compliant increases when tax non-compliant and low tax compliant individuals are being pushed to a higher category. The predicted probabilities, on the other hand, show that lower tax rates are more likely to improve tax compliance in Nigeria, especially when tax compliance is the goal and not lower categories of tax compliance.

Tax penalty reveals a positive and statistically significant relationship between tax compliance in both panels. When tax compliance is the goal, bigger tax penalties are more likely to improve tax compliance.

For the probability of no detection for tax non-compliance, the statistically significant but shows a negative relationship with tax compliance in the first panel and second panel. The odds ratio also depicts a continuous reduction in the odds for tax compliance when there is no detection of tax non-compliance. The result of the predicted probability shows that the probability of no detection should be kept low when tax compliance is in view.

The explanatory variables were tested for multicollinearity and the correlation matrix in section 2 of the appendices revealed that there is no presence of a strong positive correlation between the explanatory variables. Also, the P-value of the LR chi-square of 0.0000 shows that all the variables combined in this model are relevant and statistically significant in explaining tax compliance.

Table 2. Tax compliance and psychological factors

\begin{tabular}{llllll}
\hline Variables & $\mathbf{1}^{\text {st }}$ panel & $\mathbf{2}^{\text {nd }}$ panel & $\begin{array}{l}\text { Tax } \\
\text { non-compliance }\end{array}$ & $\begin{array}{l}\text { Low } \\
\text { compliance }\end{array}$ & Tax compliance \\
\hline S.Eco goods & $\begin{array}{l}1.015 \\
(0.765)\end{array}$ & $\begin{array}{l}1.210 \\
(0.001)\end{array}$ & High: $24 \%$ & High: $60 \%$ & High: $16 \%$ \\
\hline Tax awareness & $\begin{array}{l}1.368 \\
(0.000)\end{array}$ & $\begin{array}{l}1.054 \\
(0.337)\end{array}$ & High: $22 \%$ & High: $61 \%$ & High: $17 \%$ \\
\hline Tax fairness & $\begin{array}{l}1.513 \\
(0.000)\end{array}$ & $\begin{array}{l}1.131 \\
(0.000)\end{array}$ & High: $25 \%$ & High: $60 \%$ & High: $15 \%$ \\
\hline Tax knowledge & $\begin{array}{l}1.240 \\
(0.000)\end{array}$ & $\begin{array}{l}1.298 \\
(0.000)\end{array}$ & High: $18 \%$ & High: $61 \%$ & High: $21 \%$ \\
\hline Quality institution & $\begin{array}{l}0.872 \\
(0.000)\end{array}$ & $\begin{array}{l}0.998 \\
(0.958)\end{array}$ & High: $23 \%$ & High: $60 \%$ & High: $17 \%$ \\
\hline Citizens' voice & $\begin{array}{l}1.700 \\
(0.000)\end{array}$ & $\begin{array}{l}1.077 \\
(0.451)\end{array}$ & More: $24 \%$ & More: $60 \%$ & More: $16 \%$ \\
\hline
\end{tabular}

Source: Authors' computation

The second null hypothesis states that there is no significant relationship between being either tax non-compliant, low tax compliant or tax compliant and psychological factors in Nigeria. From Table 2, availability of socioeconomic goods is only statistically significant in the second panel, however positively related to tax compliance in both panels. Tax awareness, on the other hand, is positive and statistically significant in the first panel 
but insignificant in the second panel. Tax fairness and tax knowledge are both positive and statistically significant in both panels. Quality institutions measured by the ease of tax avoidance is negative and statistically significant only in the first panel but becomes insignificant in the second panel for tax compliance. Additionally, citizens' voice is only statistically significant in the first panel but becomes insignificant in the second panel, however positive. All the predicted probabilities for each of the psychological factors mentioned above have low values for the tax compliance category while the low tax compliance category has the bulk of the probability values.

Table 2a. Tax compliance and psychological factors (cont)

\begin{tabular}{|c|c|c|c|c|c|}
\hline Variables & $1^{\text {st }}$ panel & $2^{\text {nd }}$ panel & $\begin{array}{l}\text { Tax } \\
\text { non-compliance }\end{array}$ & $\begin{array}{l}\text { Low tax } \\
\text { compliance }\end{array}$ & Tax compliance \\
\hline Trust in govt. & $\begin{array}{l}1.217 \\
(0.000)\end{array}$ & $\begin{array}{l}1.004 \\
(0.914)\end{array}$ & High: $27 \%$ & High: $59 \%$ & High: $14 \%$ \\
\hline Beliefs & $\begin{array}{l}1.314 \\
(0.000)\end{array}$ & $\begin{array}{l}1.326 \\
(0.000)\end{array}$ & Strong: $21 \%$ & Strong: $61 \%$ & Strong: $18 \%$ \\
\hline $\begin{array}{l}\text { Paid } \\
\text { employment }\end{array}$ & $\begin{array}{l}1.089 \\
(0.000)\end{array}$ & $\begin{array}{l}1.012 \\
(0.626)\end{array}$ & Full: $23 \%$ & Full: $60 \%$ & Full: $17 \%$ \\
\hline Age-range & $\begin{array}{l}1.044 \\
(0.016)\end{array}$ & $\begin{array}{l}1.043 \\
(0.034)\end{array}$ & $\begin{array}{l}\text { High: } 22 \% \\
\text { Low: } 25 \%\end{array}$ & $\begin{array}{l}\text { High: } 60 \% \\
\text { Low: } 59 \%\end{array}$ & $\begin{array}{l}\text { High:17\% } \\
\text { Low: } 14 \%\end{array}$ \\
\hline Gender & $\begin{array}{l}1.149 \\
(0.004)\end{array}$ & $\begin{array}{l}0.922 \\
(0.142)\end{array}$ & $\begin{array}{l}\text { Male: } 24 \% \\
\text { Female: } 24 \%\end{array}$ & $\begin{array}{l}\text { Male: } 60 \% \\
\text { Female: } 60 \%\end{array}$ & $\begin{array}{l}\text { Male: } 16 \% \\
\text { Female: } 16 \%\end{array}$ \\
\hline Urbanization & $\begin{array}{l}0.806 \\
(0.000)\end{array}$ & $\begin{array}{l}0.779 \\
(0.000)\end{array}$ & $\begin{array}{l}\text { Rural: } 23 \% \\
\text { Urban: } 27 \%\end{array}$ & $\begin{array}{l}\text { Rural: } 60 \% \\
\text { Urban: } 59 \%\end{array}$ & $\begin{array}{l}\text { Rural: } 17 \% \\
\text { Urban: } 14 \%\end{array}$ \\
\hline
\end{tabular}

Source: Authors' computation

Table 2a displays the results for the remaining psychological factors employed in this study. Citizens' trust in the government is positive and statistically significant only in the first panel while citizens' beliefs remain positive and statistically significant in both panels. Having paid employment and gender are not statistically significant in the second panel, however positive. More so, a person's age-range and location (rural or urban) are positive and statistically significant in both panels. The predicted probabilities for each of the psychological factors like that of Table 2 are more for the low tax compliance category, with tax compliance having the lowest values.

The explanatory variables were tested for multicollinearity and the correlation matrix in section 2 of the appendices revealed that there is no presence of a strong positive correlation between the explanatory variables. Also, the P-value of the LR chi-square of 0.0000 shows that all the variables combined in this model are relevant and statistically significant in explaining tax compliance.

Table 3. Tax compliance and a combination of both economic and psychological factors

\begin{tabular}{|c|c|c|c|c|c|}
\hline Variables & $1^{\text {st }}$ panel & $2^{\text {nd }}$ panel & $\begin{array}{l}\text { Tax } \\
\text { non-compliance }\end{array}$ & $\begin{array}{l}\text { Low tax } \\
\text { compliance }\end{array}$ & $\begin{array}{l}\text { Tax } \\
\text { compliance }\end{array}$ \\
\hline Tax rate & $\begin{array}{l}1.152 \\
(0.001)\end{array}$ & $\begin{array}{l}1.180 \\
(0.000)\end{array}$ & $\begin{array}{l}\text { High: } 49 \% \\
\text { Low: } 9 \%\end{array}$ & $\begin{array}{l}\text { High:53\% } \\
\text { Low: } 64 \%\end{array}$ & $\begin{array}{l}\text { High: } 5 \% \\
\text { Low: } 26 \%\end{array}$ \\
\hline Tax penalty & $\begin{array}{l}2.478 \\
(0.000)\end{array}$ & $\begin{array}{l}2.706 \\
(0.000)\end{array}$ & $\begin{array}{l}\text { Big: } 4 \% \\
\text { Small: } 21 \%\end{array}$ & $\begin{array}{l}\text { Big: } 49 \% \\
\text { Small: } 66 \%\end{array}$ & $\begin{array}{l}\text { Big: } 47 \% \\
\text { Small: } 12 \%\end{array}$ \\
\hline $\begin{array}{l}\text { Probability of no } \\
\text { detection }\end{array}$ & $\begin{array}{l}0.843 \\
(0.000)\end{array}$ & $\begin{array}{l}0.855 \\
(0.000)\end{array}$ & $\begin{array}{l}\text { High: } 17 \% \\
\text { Low: } 23 \%\end{array}$ & $\begin{array}{l}\text { High: } 67 \% \\
\text { Low: } 66 \%\end{array}$ & $\begin{array}{l}\text { High: } 15 \% \\
\text { Low: } 12 \%\end{array}$ \\
\hline
\end{tabular}




\begin{tabular}{llllll}
\hline S.Eco goods & $\begin{array}{l}1.081 \\
(0.152)\end{array}$ & $\begin{array}{l}1.276 \\
(0.012)\end{array}$ & High: 19\% & High: 67\% & High: 14\% \\
\hline Tax awareness & $\begin{array}{l}1.279 \\
(0.000)\end{array}$ & $\begin{array}{l}1.066 \\
(0.324)\end{array}$ & High: 19\% & High: 67\% & High: 14\% \\
\hline Tax fairness & $\begin{array}{l}1.496 \\
(0.000)\end{array}$ & $\begin{array}{l}1.133 \\
(0.001)\end{array}$ & High: 13\% & High: 66\% & High: 21\% \\
\hline Tax knowledge & $\begin{array}{l}1.213 \\
(0.000)\end{array}$ & $\begin{array}{l}1.265 \\
(0.000)\end{array}$ & High: 16\% & High: 67\% & High: $17 \%$ \\
\hline
\end{tabular}

Source: Authors' computation

The third null hypothesis states that there is no significant relationship between being either tax non-compliant, low tax compliant or tax compliant and a combination of economic and psychological factors in Nigeria. When economic and psychological factors are combined, tax rates and tax penalties remain positive and significant in explaining the likelihood to fall into either of the tax compliance categories. Their odds ratio for being tax compliant is also higher than the other categories. Also, the probability of not being detected for tax non-compliance remain statistically significant across all the categories but it has more likelihood to put an individual in a lower tax compliance level, due to its negative regression coefficients. The provision of socioeconomic goods is positive for all categories of tax compliance. However, it is only statistically significant for predicting the exact likelihood that an individual who is tax non-compliant or low tax compliant will become tax compliant. Tax awareness, tax fairness, and tax knowledge positively determine the likelihood to fall in higher categories of tax compliance. Notwithstanding, tax awareness was only statistically significant in the first panel while tax fairness and tax knowledge were significant in both panels, with increasing odds for being tax compliant. The predicted probabilities show that low tax rates, big tax penalties, and low probabilities of no detection is more likely to put people in the compliant category.

Table 3a. Tax compliance and a combination of both economic and psychological factors (cont)

\begin{tabular}{|c|c|c|c|c|c|}
\hline Variables & $1^{\text {st }}$ panel & $2^{\text {nd }}$ panel & $\begin{array}{l}\text { Tax } \\
\text { non-compliance }\end{array}$ & $\begin{array}{l}\text { Low tax } \\
\text { compliance }\end{array}$ & Tax compliance \\
\hline $\begin{array}{l}\text { Quality } \\
\text { institution }\end{array}$ & $\begin{array}{l}0.829 \\
(0.000)\end{array}$ & $\begin{array}{l}1.059 \\
(0.126)\end{array}$ & High: $19 \%$ & High: $67 \%$ & High: $14 \%$ \\
\hline Citizens' voice & $\begin{array}{l}2.123 \\
(0.000)\end{array}$ & $\begin{array}{l}1.232 \\
(0.061)\end{array}$ & More:19\% & More: $67 \%$ & More: $14 \%$ \\
\hline Trust in govt & $\begin{array}{l}1.322 \\
(0.000)\end{array}$ & $\begin{array}{l}1.099 \\
(0.025)\end{array}$ & High: $24 \%$ & High: $65 \%$ & High: $11 \%$ \\
\hline Beliefs & $\begin{array}{l}1.325 \\
(0.000)\end{array}$ & $\begin{array}{l}1.349 \\
(0.000)\end{array}$ & Strong: $18 \%$ & Strong: $67 \%$ & Strong: $17 \%$ \\
\hline Paid employment & $\begin{array}{l}1.109 \\
(0.000)\end{array}$ & $\begin{array}{l}1.039 \\
(0.180)\end{array}$ & Full: $19 \%$ & Full: $67 \%$ & Full: $14 \%$ \\
\hline Age-range & $\begin{array}{l}1.043 \\
(0.045) \\
\end{array}$ & $\begin{array}{l}1.037 \\
(0.126) \\
\end{array}$ & $\begin{array}{l}\text { High: } 18 \% \\
\text { Low: } 21 \%\end{array}$ & $\begin{array}{l}\text { High: } 67 \% \\
\text { Low: } 66 \%\end{array}$ & $\begin{array}{l}\text { High: } 15 \% \\
\text { Low: } 12 \%\end{array}$ \\
\hline Gender & $\begin{array}{l}1.083 \\
(0.171) \\
\end{array}$ & $\begin{array}{l}0.747 \\
(0.000) \\
\end{array}$ & $\begin{array}{l}\text { Male: } 19 \% \\
\text { Female: } 13 \%\end{array}$ & $\begin{array}{l}\text { Male: } 67 \% \\
\text { Female: } 66 \%\end{array}$ & $\begin{array}{l}\text { Male: } 14 \% \\
\text { Female: } 21 \%\end{array}$ \\
\hline Urbanization & $\begin{array}{l}0.803 \\
(0.000)\end{array}$ & $\begin{array}{l}0.759 \\
(0.000)\end{array}$ & $\begin{array}{l}\text { Rural: } 19 \% \\
\text { Urban: } 23 \%\end{array}$ & $\begin{array}{l}\text { Rural: } 67 \% \\
\text { Urban: } 66 \%\end{array}$ & $\begin{array}{l}\text { Rural: } 14 \% \\
\text { Urban: } 11 \%\end{array}$ \\
\hline
\end{tabular}

Source: Authors' computation 
Quality institutions measured by the ease of avoiding taxes is only statistically significant when there are options of being either low tax compliant or tax compliant. However, its negative coefficient at this point shows a greater likelihood for the citizen to remain tax non-compliant or just be low tax compliant. While in the second panel where the option is to just be tax compliant it is positive but not statistically significant. Additionally, citizens' voice on tax issues, trust in government, paid employment, age range, and belief that taxes should be paid to the government are all positive and statistically significant in explaining the likelihood of choosing between being low tax compliant or being tax compliant. However, citizens' voice on tax issues, age-range and paid employment became statistically insignificant but still positive in the second panel. While, when explaining the likelihood of being in the tax compliant category, trust in government and citizens' belief that taxes should be paid remained positive and statistically significant. In addition, urbanisation remained negative and statistically significant across all tax compliance categories. Gender nonetheless was only significant for explaining the likelihood of being in the tax compliant category; however negative. The predicted probabilities for each psychological variable are more for the low tax compliant category than the tax compliant category. This is similar to the results obtained in the previous hypotheses.

The explanatory variables were tested for multicollinearity and the correlation matrix in section 1 of the appendices revealed that there is no presence of a strong positive correlation between the explanatory variables. Also, the P-value of the LR chi-square of 0.0000 shows that all the variables combined in this model are relevant and statistically significant in explaining tax compliance.

Table 4. Akaike Information Criteria (AIC) and Bayesian Information Criteria (BIC)

\begin{tabular}{lll}
\hline Model & AIC & BIC \\
\hline 1 & 17647.90 & 17704.85 \\
\hline 2 & 1906.23 & 19284.42 \\
\hline 3 & 13511.07 & 13734.89 \\
\hline
\end{tabular}

Source: Authors' computation

The result obtained from these information criteria showed that the model with the lowest AIC and BIC is the third model used to test hypothesis three. The model that combines both economic and psychological factors is the best model among all three models specified.

\subsection{Discussions}

When only economic factors are used, this study found that tax rates, tax penalties, and the probability of not being detected are relevant in the model of personal income tax compliance in Nigeria. Tax rates and tax penalties were found to positively explain the likelihood of a Nigerian being either tax non-compliant, low tax compliant, and tax compliant. While the probability of not being detected for tax non-compliance negatively relates to the likelihood of being in a higher tax compliance category. These findings negate the conclusions made by Alkhatib, Abdul-Jabbar and Marimuthu (2018) in their empirical research which posit that tax rates and tax penalties play no role in tax compliance among non-members of the formal economy. Meanwhile, these outcomes corroborate the postulations of Olaoye and Ekundayo (2019) which found positive relationships between tax compliance in Nigeria and tax rates, tax penalties, and tax audits. Also, the findings of this study support the postulations of the empirical research of Ozdemir, Celik and Kara (2019) which also employed the generalised ordered logistic regression and found significant a negative relationship between the probabilities of not being detected for tax non-compliance in Turkey.

It is shown that high tax rates bring about a lower likelihood of 5 percent for being in the tax compliant category, while low tax rates bring about a higher likelihood of 28 percent for being in the tax compliant category. More so, a large tax penalty will bring about a 50 percent higher likelihood of being in the tax compliant category, while a smaller tax penalty will bring about a 13 percent lower likelihood of being in the tax compliant category. Meanwhile, a low probability of not being detected for tax non-compliance brings about a higher likelihood of 16 percent to be in the tax compliant category, while a high probability of being detected culminates into a 12 percent lower probability of being in the tax compliant category. The outcome of this study also showed that a slight increase in either of the economic factors has the most likelihood of putting a Nigerian in the low tax compliant level. Existing literature has also revealed that the directly assessed personal tax system in Nigeria is made up of more tax non-compliant persons than low tax compliant persons. It is therefore not too far from reality that a slight increase in economic factors will only move most Nigerians to the low tax compliant level than any other tax compliance categories. Therefore, 
depending on the extent to which the factors are employed, there is a higher likelihood of about 45-66 percent that most personal income taxpayers in Nigeria will remain low tax compliant.

When only psychological factors are employed, this paper found positive and significant relationships between the likelihood of being in either of the tax compliance categories and urbanization, beliefs, tax knowledge, and tax fairness. Meanwhile, the other psychological variables varied across the three tax compliance categories with respect to positive or negative relationships and statistical significance. These findings are in line with the empirical outcome in the research of Ozdemir et al. (2019) as well as the study on personal income tax compliance in Nigeria and some other developing countries carried out by Nikiema and Zahonogo (2017) and Murphy, Bradford and Johnson (2016).

The outcome of this research objective shows that the a priori expectation of being in the tax compliant category based on psychological factors was met for improved socioeconomic goods, tax fairness, tax knowledge, beliefs, age-range and urbanisation. Improved socioeconomic goods provide a 16 percent higher likelihood of being in the tax compliant category, while improved tax fairness has a 15 percent higher likelihood of being in the tax compliant level. Meanwhile, tax knowledge, beliefs, and age range have higher likelihood values of 21 percent, 15 percent, and 17 percent respectively; for being in the tax compliant category. The explanation of urbanisation, however, revealed more likelihood of 17 percent for the rural population to be in the tax compliant category than a 12 percent lower likelihood to be in the tax compliant category in Nigeria. The urban areas in Nigeria are made up of more formal employment than rural areas but they both still have several informal employments that are directly assessed for personal income tax. The higher likelihood to be in the tax compliant category could be because the rural areas have many older people than the urban areas.

The findings of this paper on the achievement of the second research objective established that persons in lower age brackets have a 14 percent lower likelihood of being in the tax compliant category while individuals in the older age bracket have a 17 percent higher likelihood of being the tax compliant category. More so, citizens' trust in the government remained positive across the tax compliance categories, but in determining the likelihood of being in the tax compliant category, it became insignificant. In the empirical research of Ozdemir et al. (2019), no matter the level of trust, if there are no penalties for being caught, some persons will remain tax non-compliant or low tax compliant. In Nigeria, it could also be related to the beliefs of Nigerians about the government. If they believe that the government should not be paid taxes because they only act in their own interests, then more work and efforts need to be put in place to change these beliefs.

The outcome of this study also declared the low tax compliant category as being the category with the most likelihood of 59-61 percent for small or one unit increases in all the psychological factors. The current state of these factors in Nigeria may be very low. Consequently, the fact that there are more tax non-compliant individuals in the directly assessed personal income tax system in Nigeria makes it inevitable to see small increases in psychological factors bringing about small changes in the tax compliance rates. Furthermore, this study found similar rates for falling into either of the tax compliance categories for small increases in paid employment and rural population. This could be explained in respect to low after-tax income which pushes persons with paid employments to also source for other income venture in the informal sector. However, the above explanation is not certain and considerations by future researchers will further enhance the value of this research endeavour. Also, male and female gender showed the same likelihood values across each of the tax compliance categories. This could mean that whether a person is a man or a woman, it is his/her perception of the tax system that matters and not the gender. Further research effort can, however, be channelled towards this angle to provide more empirical information.

When both economic and psychological factors are combined, this paper found positive and statistically significant relationships between either of the categories of tax compliance and trust in government, beliefs, tax fairness, tax knowledge, tax penalty, tax rates, probability of not being detected and urbanisation. These findings support the empirical research on personal income tax compliance of Ozdemir et al. (2019), Oladipupo and Obazee (2016) and Murphy et al. (2015). The employment of economic factors alone and a combination of economic and psychological factors in the model of personal income tax compliance in Nigeria showed that all the economic factors remained significant and met a priori expectations. However, when psychological factors are combined with economic factors, only some psychological factors conform to a priori expectations. These factors are tax rates, tax penalties, probability of not being detected, improved socioeconomic goods, tax fairness, tax knowledge, trust in government, beliefs, gender and urbanisation. From this finding, it is revealed that trust in government and gender are added to and age-range was subtracted from the positive and significant collection of variables with the likelihood of moving tax non-compliant Nigerians to the tax compliant category. Perhaps, age-range became insignificant because tax penalties were added to the equation and thus, taxable individuals know that irrespective of their age, if they are 
caught for tax non-compliance, they would be punished.

The likelihood of being in the tax compliant category, based on the factors that met a priori expectations, did not show many changes from the use of either of the factors. Low tax rate still has a higher likelihood of being in the tax compliant regime than high tax rates. This however reduced by 2 percent. More so, large tax penalties still have a higher likelihood of being in the tax compliant regime than small penalties. This however reduced by 3 percent. A similar occurrence exists for low probability of not being detected when compared with a high probability of not being detected. It only reduced by 1 percent. When there are deeper beliefs that taxes are to be paid to the government, the likelihood of being in the tax compliant category increased by 2 percent. For higher tax knowledge and tax fairness, the rate reduced by 3 and 1 percent respectively. The difference in the likelihood values for each factor when employed alone and when combined perhaps reflect different combination levels. Given the psychological nature of economic decisions, it is arguable that economic and psychological factors regarding tax compliance are interactive and cross re-enforcing. Though, not obvious from the result here perhaps, the application of other econometric methods to the data could offer more interesting outcomes.

From the findings of this paper, the economic factor with the most likelihood of moving a Nigerian to the tax compliant regime is tax penalty. This outcome is buttressed in the model estimated for just economic factors as well as the model that combined the factors. This finding explains the reality of the behaviour of directly assessed personal income taxpayers. Majority of them are tax non-compliant but increasing tax penalties will move them to higher categories of tax compliance in Nigeria. However, as already revealed from this research finding, a proper mix of these factors must be sought after, even when the most significant factors are being combined. On the other hand, the most impactful psychological factor which is more likely to move tax non-compliant Nigerians to the tax compliant regime is citizens' belief that taxes are to be paid to the government. If people do not think that taxes should be paid due to their perceptions of the government, then tax compliance would remain enforced. This factor is the most important psychological factor and therefore, calls for a reorientation of the mindset of Nigerians through different mechanisms.

\section{Conclusion and Recommendations}

This study started with a broad four-sided objective to understand and provide insight on the extent to which economic factors, psychological factors and a combination of both factors move personal income taxpayers to either tax non-compliant, low tax compliant, or tax compliant categories of tax compliance. In addition, the most impactful economic and psychological factor with the highest likelihood of the taxpayers falling into the tax compliant category was also to be ascertained. These objectives were to be achieved by employing the generalised ordered logistic regression analysis.

To understand why personal income tax compliance has been low in Nigeria, this study revealed that a greater focus on economic factors will continue to breed low personal income tax compliance. It should, however, be noted that economic factors in themselves are very necessary for instilling tax compliance among the personal income taxpayers in Nigeria as well as psychological factors, which when employed alone has a high probability of improving personal income tax compliance in Nigeria, but the likelihood value is higher when these factors are combined with economic factors.

The climax of this study concludes that economic and psychological factors are to be combined to push personal income taxpayers in Nigeria from the category of being tax non-compliant to the tax compliant category. Also, to speedily improve personal income tax compliance in Nigeria, tax penalty and citizens' belief that taxes are to be paid to the government are the most impactful economic and psychological factors respectively.

Having successfully answered the research questions and fulfilled the research objectives of this research, this paper recommends that policymakers in Nigeria and other developing countries use the peculiar features of their tax system to implement policy measures to increase the number of compliant personal income taxpayers. These peculiar features could be the number of tax non-compliant individuals, the extent to which economic and psychological factors have to be improved as well as time considerations in the use of these factors to yield desired objectives. In addition, effective reorientation measures are needed to change the mindset of Nigerians about the selfish intentions of government officials. The following measures would suffice: improving tax education, allowing citizens to voice their opinions and worries on tax-related issues as well as ensuring that the tax system remains transparent.

One of the limitations of this study is that the quantitative household survey dataset employed in this study did not account for the role of time in moving tax non-compliant persons to the tax compliant category. Further research should, therefore, be conducted in this regard to proffer more explanations on how the factors for tax compliance 
interact. Also, the interactive and cross re-enforcing effects of economic and psychological factors can be ascertained using other research methods that adequately capture this.

\section{References}

Alasfour, F. (2019). Costs of distrust: The virtuous cycle of tax compliance in Jordan. Journal of Business Ethics, $155(1), 243-258$.

Ali, M., Fjeldstad, O. H., \& Sjursen, I. H. (2013). Factors affecting tax compliant attitude in Africa: Evidence from Kenya, Tanzania, Uganda and South Africa. In Centre for the Study of African Economies 2013 Conference, Oxford University.

Alkhatib, A. A., Abdul-Jabbar, H., \& Marimuthu, M. (2018). The effects of deterrence factors on income tax evasion among Palestinian SMEs. International Journal of Academic Research in Accounting, Finance and Management Sciences, 8(4), 144-152.

Allingham, M. G., \& Sandmo, A. (1972). Income tax evasion, a theoretical analysis. Journal of Public Economics, 1, 323-338.

Alm, J., Jackson, B., \& McKee, M. (1992). Deterrence and beyond: Toward a kinder, gentler IRS. In J. Slemrod (Ed.), Why People Pay Taxes: Tax Compliance and Enforcement (Vol. 1, pp. 311-329). University of Michigan Press, Ann Arbor.

Ameyaw, B., Oppong, A., Abruquah, L. A., \& Ashalley, E. (2016). Informal sector tax compliance issues and the causality nexus between taxation and economic growth: Empirical evidence from Ghana. Modern Economy, 7(12), 1478-1497.

Ayuba, A., Saad, N., \& Ariffin, Z. Z. (2018). Testing the Assumptions of Slippery Slope Framework on Tax Compliance: Evidence from Nigerian SMEs. DLSU Business \& Economics Review, 27(2), 166-178.

Azjen, I. (1991). Organizational Behaviour and Human Decision Processes: The Theory of Planned Behavior. Organizational Behaviour Journal 50(9), 179-211.

Bird, R., \& Davis-Nozemack, K. (2018). Tax avoidance as a sustainability problem. Journal of Business Ethics, 151(4), 1009-1025.

Braithwaite, B. (2009). Taxing Democracy: Understanding tax Avoidance and tax evasion. Aldershot, United Kingdom.

Brooks, N. (2001). Key Issues in Income Tax: Challenges of Tax Administration and Compliance. A paper for the Asian Development Bank.

Da Silva, F. P., Guerreiro, R., \& Flores, E. (2019). Voluntary versus enforced tax compliance: the slippery slope framework in the Brazilian context. International Review of Economics, 66(2), 147-180.

De Neve, J. E., Imbert, C., Spinnewijn, J., Tsankova, T., \& Luts, M. (2019). CEP Discussion Paper No 1621 May 2019 How to Improve Tax Compliance? Evidence from Population-wide Experiments in Belgium.

Feld, L., \& Frey, B. (2006). Tax compliance as the result of a psychological Tax Contract: The Role of Incentives and Responsive regulation. Law and Policy January, 15(1), 102-120.

Gaspar, V., Amaglobeli, M. D., Garcia-Escribano, M. M., Prady, D., \& Soto, M. (2019). Fiscal Policy and Development: Human, Social, and Physical Investments for the SDGs. International Monetary Fund.

Gobena, L. B., \& Van Dijke, M. (2017). Fear and caring: Procedural justice, trust, and collective identification as antecedents of voluntary tax compliance. Journal of Economic Psychology, 62, 1-16.

Gupta, S., \& Plant, M. (2019). Enhancing Domestic Resource Mobilization: What are the Real Obstacles?. Retrieved from https://www.cgdev.org/blog/enhancing-domestic-resource-mobilization-what-are-real-obstacles

Haning, M. T., \& Hasniati, M. H. (2019). Investigating the Effect of Public Trust on Tax Compliance. Bisnis \& Birokrasi Journal, 26(2).

IMF. (2015). Current Challenges in Revenue Mobilisation Improving Tax Compliance. International Monetary Fund. Washington DC.

International Center for Tax and Development. (2019, March 25). What Nigerians really think about tax. Retrieved February 16, 2020, from https://www.ictd.ac/blog/what-nigerians-really-think-about-tax/

International Monetary Fund, Fiscal Monitor. (2018). Capitalizing on the good times. Retrieved from 
www.imfconnect.org/content/dam/imf/Spring-Annual\%20Meetings/SM18/Documents\%20and\%20Publications /fm1801.pdf

Jayawardane, D. (2015). Psychological factors affect tax compliance-A review paper. International Journal of Arts and Commerce, 4(6), 131-141.

Kangave, J., Nakato, S., Waiswa, R., Nalukwago, M., \& Zzimbe, P. (2018). What Can We Learn from the Uganda Revenue Authority's Approach to Taxing High Net Worth Individuals?

Keen, M., Toro, J., Baer, K., Perry, V., Norregaard, J., Ueda, J., ... Rojas, E. (2015, April). Current Challenges in Revenue Mobilization: Improving Tax Compliance. Staff Rep., 1-79.

Kirchler, E. (2007). The Economic Psychology of Tax behaviour. Cambridge University Press, Cambridge, England.

Kirchler, E. (2019). Strengthening Tax Compliance by Balancing Authorities' Power and Trustworthiness. WU International Taxation Research Paper Series (2019-03).

Koessler, A. K., Torgler, B., Feld, L. P., \& Frey, B. S. (2019). Commitment to pay taxes: Results from field and $\begin{array}{lllll}\text { laboratory experiments. } & \text { European }\end{array}$ https://doi.org/10.1016/j.euroecorev.2019.02.006

Krishnan, R., Marinich, E., \& Shields, M. (2012). Participative Budgeting, Psychological contracts, and Honesty of Communication.

Mas'ud, A., Manaf, N. A. A., \& Saad, N. (2014, August). Do Trust and Power Moderate Each Other in Relation to Tax Compliance?. Procedia - Social and Behavioral Sciences, 164, 49-54. https://doi.org/10.1016/j.sbspro.2014.11.049

Murphy, K., Bradford, B., \&Jackson, J. (2016). Motivating Compliance Behavior Among Offenders: Procedural Justice or Deterrence? Criminal Justice and Behavior, 43(1), 102-118. https://doi.org/10.1177/0093854815611166

Newman, W., Charity, M., \& Ongayi, W. (2018). Literature review on the impact of tax knowledge on tax compliance among small medium enterprises in a developing country. International Journal of Entrepreneurship, 22(4), 1-15.

Nigerian Economic Summit Group-NESG household survey dataset. (2018). Retrieved from https://www.ictd.ac/dataset/nesg-nigeria-tax-subsidy-perception-dataset/

Nikiema, R., \& Zahonogo, P. (2017). Taxpayer behaviour and institutions in Sub-Saharan Africa.

Oladele, R., Aribaba, F. O., Olamide Ahmodu, A. L., Yusuff, S. A., \& Alade, M. (2019). Tax Enforcement Tools and Tax Compliance in Ondo State, Nigeria. Academic Journal of Interdisciplinary Studies, 8(2), 27-38. https://doi.org/10.2478/ajis-2019-0013

Oladipupo, A., \& Obazee, U. (2016). Tax knowledge, penalties and Tax compliance in Small and Medium Scale Enterprises in Nigeria. iBusiness, 8, 1-9. https://doi.org/10.4236/ib.2016.81001

Olaoye, C. O., \& Ekundayo, A. T. (2019). Effects of Tax Audit on Tax Compliance and Remittance of Tax Revenue in Ekiti State.

Özdemir, D., Çelik, A. K., \& Kara, S. B. (2019). Analyzing Factors Affecting Tax Morale Levels in Turkey Using Alternative Ordered Response Models. Transylvanian Review of Administrative Sciences, 15(57), 86-102.

Pfister, M. (2009).Taxation for Investment and Development: An Overview of Policy Challenges in Africa. Ministerial Meeting and Expert Roundtable. NEPAD - OECD. African Investment Initiative

Pricewaterhousecoopers. (2017, July 26). Taxation: Endless game and endless controversy. Retrieved February 16, 2020, from https://www.pwc.com/ng/en/assets/pdf/tax-winning-article-media-awards-2017.pdf

Prichard, W., Lustig, N., Gupta S., Krafchik, W., Gary, I., \& Coulibaly, B. (2019). Tax to finance the SDGs, but not to undermine them. Retrieved from https://www.brookings.edu/blog/africa-in-focus/2019/07/01/tax-to-finance-the-sdgs-but-not-to-undermine-them/

Radulović, B. (2019). Morality of informality: Tax morale in the Serbian business sector: An empirical investigation. Industrija, 47(1), 43-60.

Sandmo, A. (2004). The Theory of Tax Evasion: Retrospective view. Discussion Paper 31/-4, Norwegian School of Economics and Business Administration. 
Supriyadi, M. W. (2017). Beyond deterrence: an empirical and experimental analysis of tax compliance behavior in Indonesia. (Tese de Doutorado). $\quad$ Retrieved from https://www.inderscienceonline.com/doi/abs/10.1504/IJTGM.2014.064911

Taiwo, O., \& Erikume, K. (2019). Tax Data Card Nigeria 2019. Retrieved from https://www.pwc.com/ng/en/assets/pdf/2019-ngr-tax-data-card.pdf

Uadiale, O. M., Fagbemi, T. O., \& Ogunleye, J. O. (2010). An Empirical Study of the Relationship between Culture and Personal Income Tax Evasion in Nigeria. European Journal of Economics, Finance and Administrative Sciences, 20, 116-126.

Umar, M. A., Derashid, C., Ibrahim, I., \& Bidin, Z. (2019). Public governance quality and tax compliance behavior in developing countries: The mediating role of socioeconomic conditions. International Journal of Social Economics, 46(3), 338.

Umar, M. A., Derashid, C., Muse, O., \& Popoola, J. (2019). A Multidimensional Framework for Understanding Tax Audit Effectiveness in Developing Countries. Indian-Pacific Journal of Accounting and Finance, 3(2), 4-14.

United Nations. (2017). 2015 Sustainable Development Goals Report. United Nations Secretary General.

Van Dijke, M., Gobena, L. B., \& Verboon, P. (2019, July). Make me want to pay. A three-way interaction between procedural justice, distributive justice, and power on voluntary tax compliance. Frontiers in Psychology, 10, 1-15. https://doi.org/10.3389/fpsyg.2019.01632

Williams, R. (2006). Generalized ordered logit/partial proportional odds models for ordinal dependent variables. The Stata Journal, 6(1), 58-82.

World Bank. (2018). Domestic Resource Mobilization. Retrieved from https://www.worldbank.org/en/topic/governance/brief/domestic-resource-mobilization

Yemi, O. (2018, May 17). VP Osinbajo at the CITN Annual Tax Conference (Full Speech) On 09/05/2018. Retrieved February 16, 2020, from https://www.yemiosinbajo.ng/vp-osinbajo-at-the-citn-annual-tax-conference-full-speech-on-09-05-2018/

Yesegat, W. A., \& Fjeldstad, O. H. (2016). Business People's Views of Paying Taxes in Ethiopia.

Youde, S., \& Lim, S. (2019). The Determinants of Medium Taxpayers' Compliance Perspectives: Empirical Evidence from Siem Reap Province, Cambodia. International Journal of Public Administration, 1-12.

\section{Appendices}

Section 1. Correlation matrix

\begin{tabular}{|c|c|c|c|c|c|}
\hline e (V) & q34 & q33 & q35d & $\begin{array}{l}\text { cut1 } \\
\quad \text { cons }\end{array}$ & $\begin{array}{l}\text { cut2 } \\
\quad \text { cons }\end{array}$ \\
\hline q34 & & & & & \\
\hline $\begin{array}{l}q 39 \\
\text { q33 }\end{array}$ & $\begin{array}{r}1.0000 \\
-0.0352\end{array}$ & 1.0000 & & & \\
\hline q35d & 0.0005 & 0.0211 & 1.0000 & & \\
\hline
\end{tabular}




\begin{tabular}{|c|c|c|c|c|c|c|c|c|c|c|c|c|}
\hline$e(V)$ & $\begin{array}{l}\text { q34 } \\
\\
q 44\end{array}$ & q20c & q48a & q28a & q29a & q58 & q49_e & $q 42 a$ & q8 & $\mathrm{q} 1 \mathrm{~b}$ & gender & urbani n \\
\hline \multicolumn{13}{|l|}{ q34 } \\
\hline q44 & 1.0000 & & & & & & & & & & & \\
\hline q20c & -0.0285 & 1.0000 & & & & & & & & & & \\
\hline q48a & -0.0186 & -0.0156 & 1.0000 & & & & & & & & & \\
\hline q28a & -0.0367 & -0.1117 & -0.0692 & 1.0000 & & & & & & & & \\
\hline q29a & 0.0183 & -0.0330 & -0.0297 & -0.2564 & 1.0000 & & & & & & & \\
\hline q58 & -0.0042 & 0.0329 & 0.0405 & 0.0656 & 0.0707 & 1.0000 & & & & & & \\
\hline q49_e & -0.0303 & -0.0102 & 0.0131 & -0.0114 & 0.0075 & 0.0230 & 1.0000 & & & & & \\
\hline q42a & -0.2356 & -0.0260 & -0.0103 & -0.0929 & -0.0596 & -0.0192 & 0.0099 & 1.0000 & & & & \\
\hline q8 & -0.0212 & -0.1253 & 0.0158 & -0.0299 & 0.0182 & -0.0040 & -0.0557 & -0.0654 & 1.0000 & & & \\
\hline $\mathrm{q} 1 \mathrm{~b}$ & -0.0092 & -0.0795 & 0.0024 & -0.0010 & -0.0045 & 0.0101 & -0.0061 & 0.0049 & -0.1931 & 1.0000 & & \\
\hline gender & 0.0227 & 0.0564 & 0.0394 & 0.0295 & 0.0193 & 0.0412 & -0.0476 & 0.0185 & 0.1645 & 0.0464 & 1.0000 & \\
\hline urbanization & 0.0205 & 0.0076 & 0.0125 & 0.0578 & -0.0023 & -0.0162 & -0.0016 & 0.0399 & 0.0119 & -0.0347 & 0.0101 & 1.0000 \\
\hline
\end{tabular}

. estat vce, correlation

Correlation matrix of coefficients of ologit model

\begin{tabular}{|c|c|c|c|c|c|c|c|c|c|c|c|c|}
\hline$e(V)$ & $\begin{array}{l}\text { q34 } \\
\\
\text { q39 }\end{array}$ & q33 & q35d & q44 & q20c & q48a & q28a & q29a & q58 & q49_e & $\mathrm{q} 42 \mathrm{a}$ & q8 \\
\hline \multicolumn{13}{|l|}{ q34 } \\
\hline q39 & 1.0000 & & & & & & & & & & & \\
\hline q33 & -0.0371 & 1.0000 & & & & & & & & & & \\
\hline q35d & 0.0154 & 0.0226 & 1.0000 & & & & & & & & & \\
\hline q44 & 0.0675 & 0.0207 & 0.0248 & 1.0000 & & & & & & & & \\
\hline q20c & 0.0307 & 0.0108 & -0.0060 & -0.0085 & 1.0000 & & & & & & & \\
\hline q48a & -0.0696 & 0.0302 & 0.1062 & -0.0129 & -0.0094 & 1.0000 & & & & & & \\
\hline q28a & 0.0047 & -0.0081 & 0.0282 & -0.0287 & -0.0801 & -0.0723 & 1.0000 & & & & & \\
\hline q29a & -0.1107 & -0.0232 & -0.0742 & 0.0103 & -0.0303 & -0.0341 & -0.2551 & 1.0000 & & & & \\
\hline q58 & 0.0769 & 0.0553 & -0.0468 & -0.0028 & 0.0362 & 0.0375 & 0.0654 & 0.0774 & 1.0000 & & & \\
\hline q49_e & -0.0079 & 0.0170 & -0.0128 & -0.0185 & -0.0076 & -0.0035 & -0.0108 & 0.0061 & 0.0290 & 1.0000 & & \\
\hline$q 42 a$ & 0.0723 & -0.0100 & -0.0611 & -0.2069 & -0.0235 & -0.0011 & -0.0833 & -0.0630 & -0.0084 & 0.0124 & 1.0000 & \\
\hline q8 & -0.0123 & -0.0028 & -0.0215 & -0.0308 & -0.1046 & 0.0145 & -0.0166 & 0.0296 & -0.0082 & -0.0625 & -0.0644 & 1.0000 \\
\hline$q 1 b$ & 0.0601 & 0.0009 & 0.0114 & 0.0022 & -0.0810 & -0.0078 & 0.0020 & -0.0055 & 0.0116 & -0.0039 & 0.0029 & -0.1915 \\
\hline gender & -0.0123 & -0.0460 & 0.0035 & 0.0433 & 0.0612 & 0.0380 & 0.0260 & 0.0108 & 0.0438 & -0.0406 & 0.0127 & 0.1630 \\
\hline urbanization & 0.0096 & -0.0116 & -0.0046 & 0.0160 & 0.0095 & -0.0053 & 0.0652 & -0.0009 & -0.0233 & -0.0138 & 0.0422 & 0.0228 \\
\hline
\end{tabular}

\section{Section 2. Results for hypothesis one}

\section{Section 2.1 Generalised ordered logistic regression}

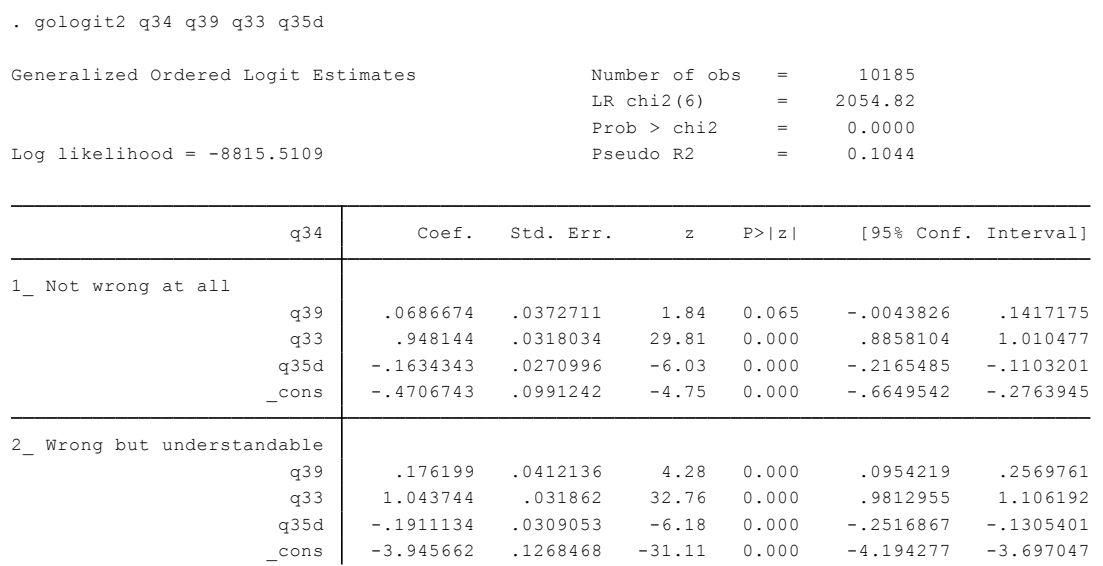




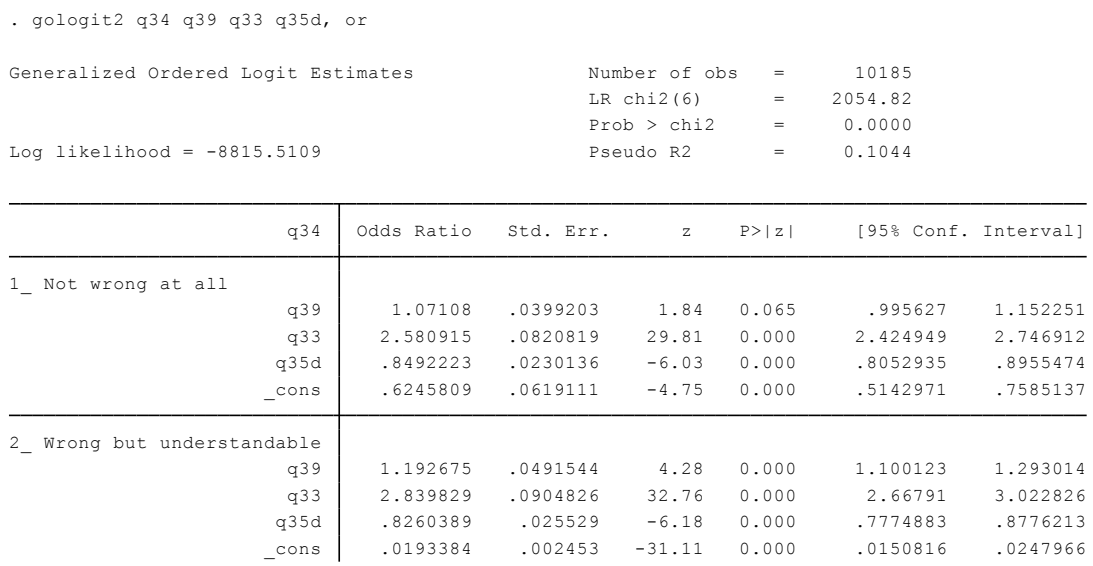

\section{Section 3. Result for hypothesis two}

\section{Section 3.1 Generalised ordered logistic regression result}

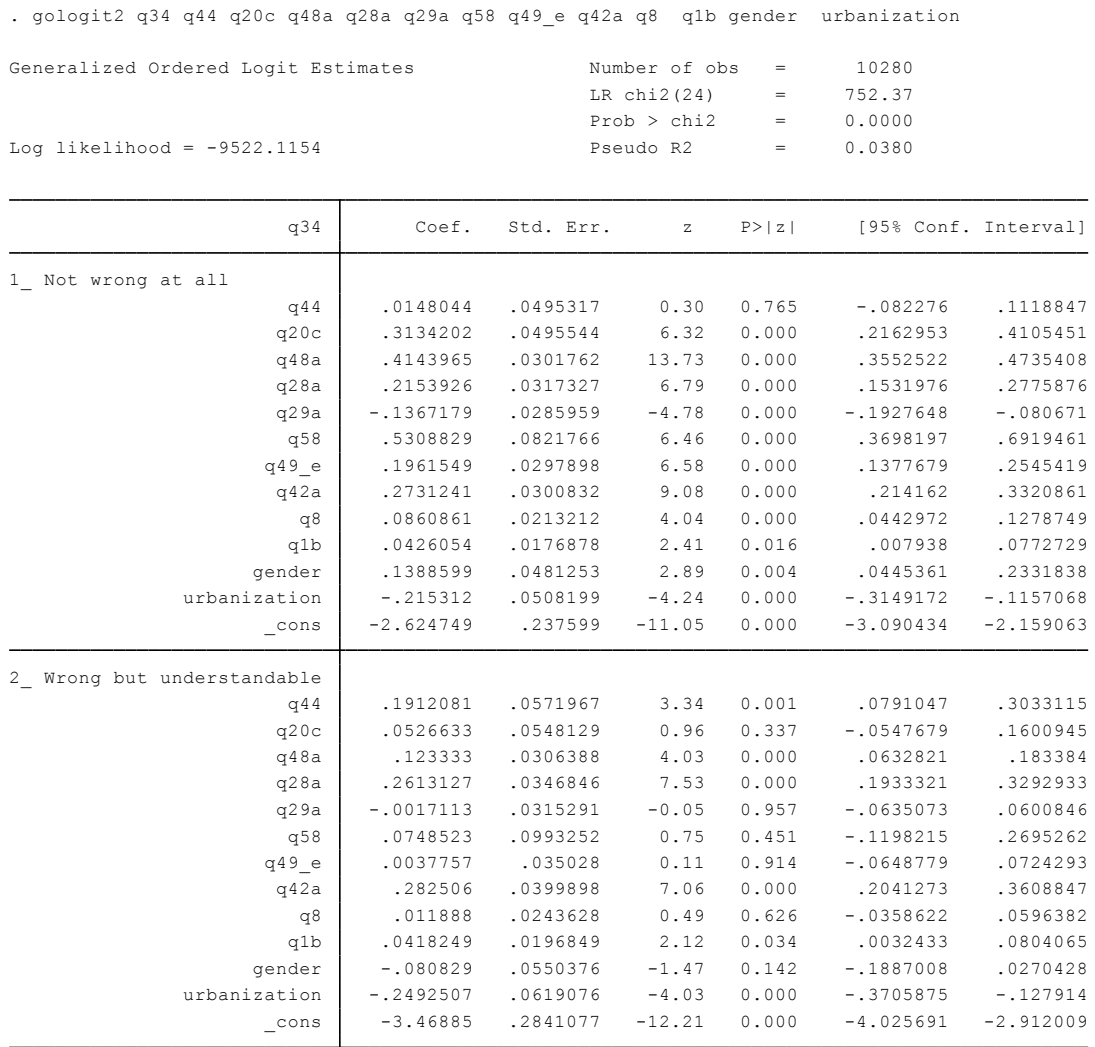




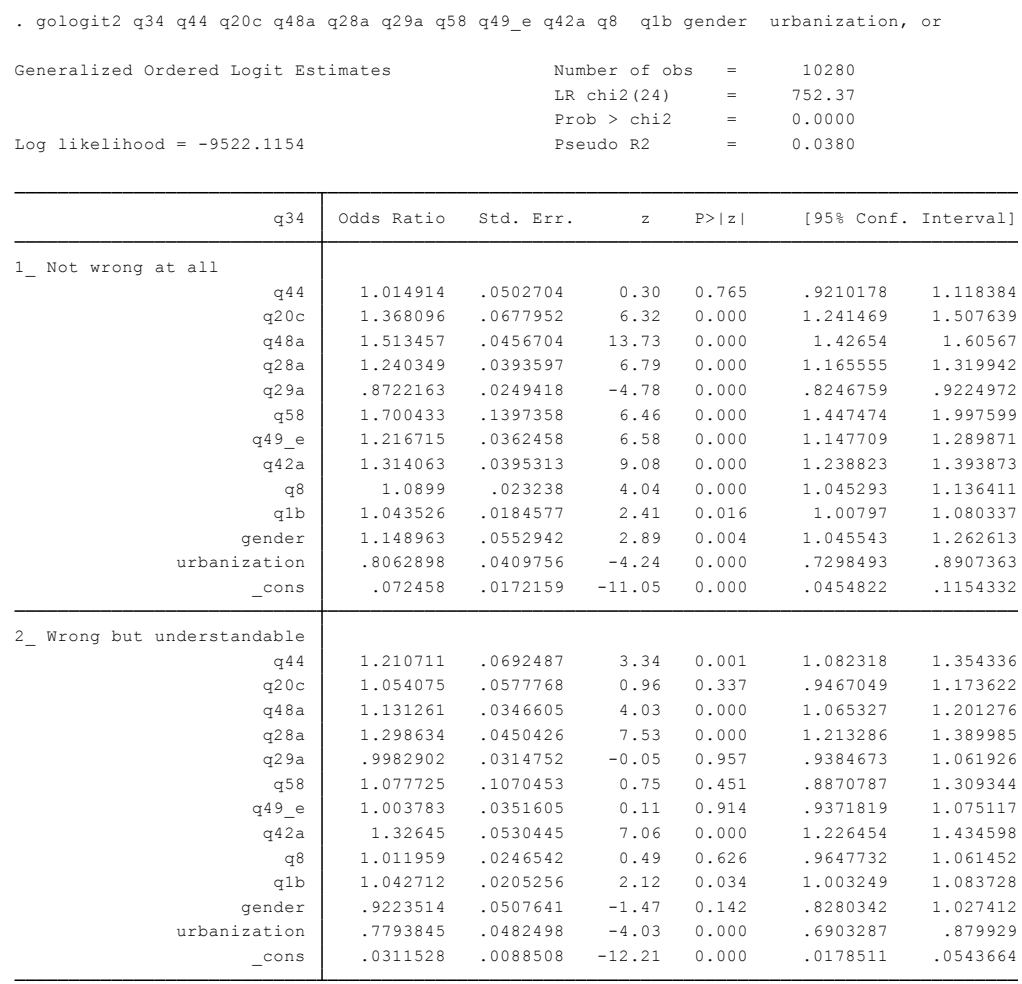

Section 4. Results for hypothesis three

Section 4.1 Generalised ordered logistic regression

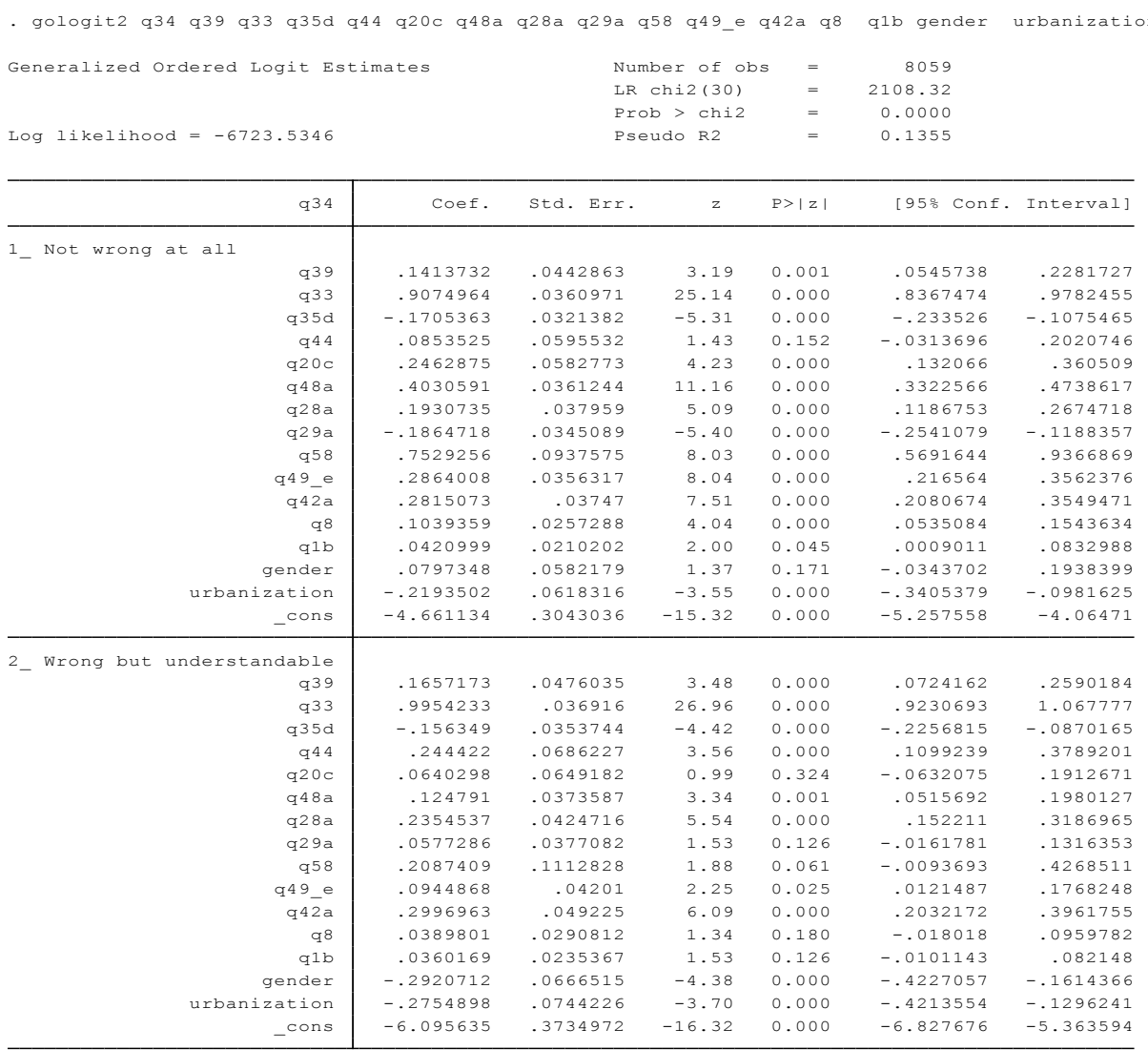




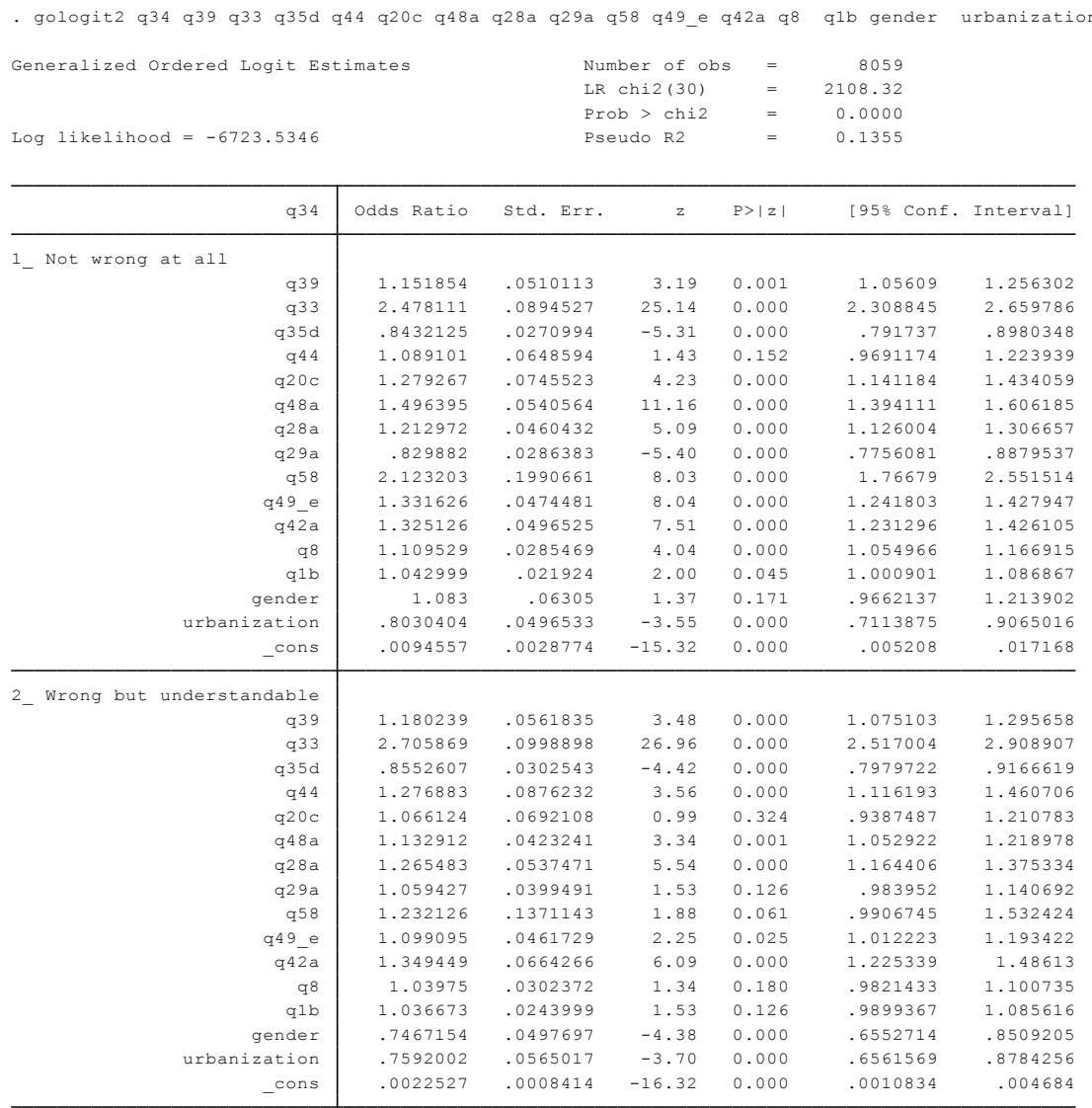

Section 5. Akaike and Bayesian Information Criteria

- estat ic

Akaike's information criterion and Bayesian information criterion

\begin{tabular}{c|cccccc}
\hline Model & Obs & Il (null) & 11 (model) & df & AIC & BIC \\
\hline$\cdot$ & 10185 & -9842.92 & -8815.511 & 8 & 17647.02 & 17704.85 \\
\hline & Note: & N=Obs used in calculating & BIC; see $\underline{\text { [R] BIC note }}$
\end{tabular}

. estat ic

Akaike's information criterion and Bayesian information criterion

\begin{tabular}{|c|c|c|c|c|c|c|}
\hline Model & obs & $11($ null) & 11 (model) & $d f$ & AIC & BIC \\
\hline . & 10185 & -9842.92 & -8815.511 & 8 & 17647.02 & 17704.85 \\
\hline \multicolumn{7}{|c|}{ Note: $N=O b s$ used in calculating BIC; see $\underline{[R] \text { BIC note }}$} \\
\hline \multicolumn{3}{|c|}{ Akaike's information criterion and } & \multicolumn{4}{|c|}{ Bayesian information criterion } \\
\hline Model & Obs & $11($ null) & 11 (model) & $d f$ & AIC & BIC \\
\hline . & 8059 & -7777.693 & -6723.535 & 32 & 13511.07 & 13734.89 \\
\hline
\end{tabular}

Note: N=Obs used in calculating BIC; see [R] BIC note 
Section 6. Data measurement

The dependent variable:

\begin{tabular}{llrl}
\hline Variable & Indicator & Response categories \\
\hline Tax compliance & Q34: & 1 . Not wrong at all \\
& Perception of citizens that do not & 2 . Wrong and understandable \\
& pay their taxes. & 3 . Wrong and punishable \\
\hline
\end{tabular}

Source: Author's computation (2020)

The independent variables:

\begin{tabular}{|c|c|c|c|}
\hline Variable & Factor type & Indicator & Response categories \\
\hline Tax rate & Economic & $\begin{array}{l}\text { Q39: Pay more or fewer } \\
\text { taxes now, compared to } 3 \\
\text { years ago }\end{array}$ & $\begin{array}{ll}\text { 1. } & \text { More } \\
\text { 2. About the same } \\
\text { amount } \\
\text { 3. Less }\end{array}$ \\
\hline Tax penalty & Economic & $\begin{array}{l}\text { Q33: perception of the } \\
\text { penalty when caught for } \\
\text { not paying taxes }\end{array}$ & $\begin{array}{ll}\text { 1. } & \text { Nothing } \\
\text { 2. } & \text { Small } \\
\text { 3. } & \text { Medium } \\
\text { 4. } & \text { Large } \\
\end{array}$ \\
\hline $\begin{array}{l}\text { Probability of being } \\
\text { detected }\end{array}$ & Economic & $\begin{array}{l}\text { Q35d: I would not pay } \\
\text { my taxes if I would not } \\
\text { get caught }\end{array}$ & $\begin{array}{ll}\text { 1. Disagree } \\
\text { 2. Neither agree nor } \\
\text { disagree } \\
\text { 3. Agree }\end{array}$ \\
\hline $\begin{array}{ll}\text { Provision } & \text { of } \\
\text { socioeconomic goods }\end{array}$ & Psychological & $\begin{array}{l}\text { Q44: pay higher taxes for } \\
\text { better goods and services }\end{array}$ & $\begin{array}{ll}0 . & \text { Disagree } \\
\text { 1. } & \text { Agree } \\
\end{array}$ \\
\hline Tax awareness & Psychological & $\begin{array}{l}\text { Q20c: required to pay } \\
\text { taxes }\end{array}$ & $\begin{array}{l}\text { 0. No } \\
\text { 1. Yes }\end{array}$ \\
\hline Tax fairness & Psychological & $\begin{array}{l}\text { Q48a: trust in the tax } \\
\text { officials to collect tax } \\
\text { fairly }\end{array}$ & $\begin{array}{ll}\text { 1. } & \text { Don't trust } \\
\text { 2. } & \text { Trust a little } \\
\text { 3. } & \text { Trust somewhat } \\
\text { 4. } & \text { Trust a lot }\end{array}$ \\
\hline Tax knowledge & Psychological & $\begin{array}{l}\text { Q28a: Ease of finding out } \\
\text { taxes to be paid }\end{array}$ & $\begin{array}{ll}\text { 1. } & \text { Very difficult } \\
\text { 2. difficult } \\
\text { 3. easy } \\
\text { 4. } \\
\end{array}$ \\
\hline Quality institutions & Psychological & $\begin{array}{l}\text { Q29a: Ease of avoiding } \\
\text { taxes }\end{array}$ & $\begin{array}{l}\text { 1. Difficult } \\
\text { 2. Neither difficult or } \\
\text { easy } \\
\text { 3. Easy }\end{array}$ \\
\hline $\begin{array}{l}\text { Harnessing citizens' } \\
\text { opinion }\end{array}$ & Psychological & $\begin{array}{l}\text { Q58: Have you been } \\
\text { asked to express your } \\
\text { views on tax issues by the } \\
\text { government? }\end{array}$ & $\begin{array}{l}\text { 1. No } \\
\text { 2. Yes }\end{array}$ \\
\hline $\begin{array}{l}\text { Trust in government and } \\
\text { tax authority }\end{array}$ & Psychological & $\begin{array}{l}\text { Q49_e: } \\
\text { government and tax } \\
\text { authorities act more for } \\
\text { the good of Nigerians or } \\
\text { for their own personal } \\
\text { interests? }\end{array}$ & $\begin{array}{l}\text { 1. Acts more for the good } \\
\text { of the people } \\
\text { 2. Acts more for their } \\
\text { own interest }\end{array}$ \\
\hline Citizens' Beliefs & Psychological & $\begin{array}{l}\text { Q42a: Should citizens } \\
\text { pay their taxes for the } \\
\text { development of the }\end{array}$ & $\begin{array}{ll}\text { 1. Disagree } \\
\text { 2. Neither agree nor } \\
\text { disagree }\end{array}$ \\
\hline
\end{tabular}




\begin{tabular}{|c|c|c|c|}
\hline & & Nation & 3. Agree \\
\hline Paid employment & Psychological & $\begin{array}{l}\text { Q8: Do you have a paid } \\
\text { employment }\end{array}$ & $\begin{array}{ll}\text { 1. } & \text { No (not looking) } \\
\text { 2. } & \text { No (looking) } \\
\text { 3. } & \text { Part-time } \\
\text { 4. } & \text { Full-time } \\
\end{array}$ \\
\hline Age range & Psychological & Q1b & $\begin{array}{ll}1 . & 18-24 \\
2 . & 25-31 \\
3 . & 32-38 \\
\text { 4. } & 39-45 \\
5 . & 46-52 \\
6 . & 52 \text { and above }\end{array}$ \\
\hline Gender & Psychological & Gender & $\begin{array}{ll}\text { 1. } & \text { Male } \\
\text { 2. } & \text { Female } \\
\end{array}$ \\
\hline Urbanization & Psychological & Urbanization & $\begin{array}{ll}0 . & \text { rural } \\
1 . & \text { urban } \\
\end{array}$ \\
\hline
\end{tabular}

Source: Authors' computation 